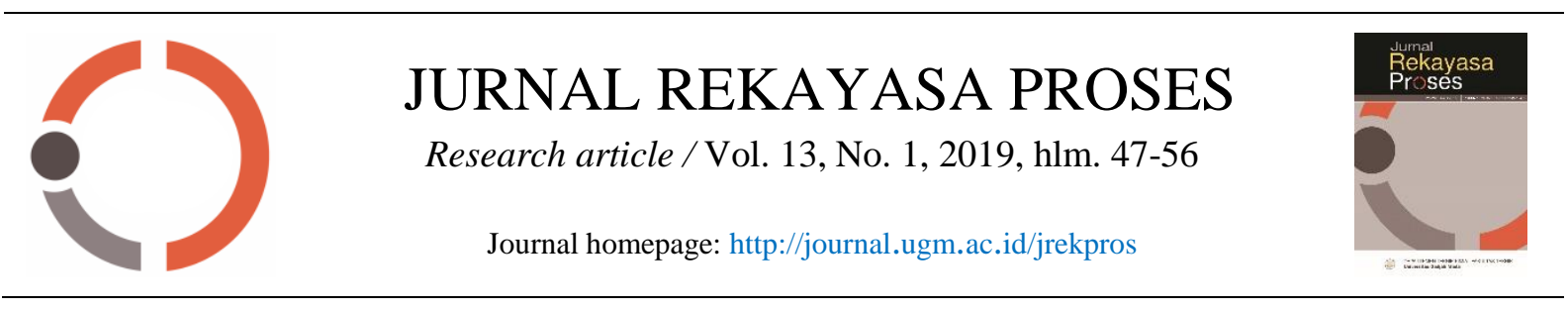

\title{
Pengaruh Komposisi Subtrat dari Campuran Kotoran Sapi dan Rumput Gajah (Pennisetum purpureum) terhadap Produktivitas Biogas pada Digester Semi Kontinu
}

\author{
Agus Haryanto ${ }^{*}$, Rivan Okfrianas, dan Winda Rahmawati \\ Jurusan Teknik Pertanian, Fakultas Pertanian, Universitas Lampung \\ Jl Soemantri Brojonegoro No. 1 Kampus Gedong Meneng, 35145 Bandar Lampung \\ *Alamat korespondensi: agus.haryanto@fp.unila.ac.id
}

(Submisi: 20 November 2018; Revisi: 4 April 2019; Penerimaan: 13 April 2019)

\section{A B S T RACT}

This study aims to determine the effect of substrate composition on biogas production from a mixture of cow dung and elephant grass using semi-continuous digester. Fresh cow dung and elephant grass were obtained from Department of Animal Husbandry, Faculty of Agriculture, University of Lampung. Elephant grass was knife-chopped, crushed using a blender and then mixed with cow dung at a total solid (TS) ratio between elephant grass and cow dung varies from 35:65 (P1), 40:60 (P2), 45:55 (P3), and 50:50 (P4). This mixture was then diluted with tap water until its TS content reach 5\% and was used as substrate. Four semi-continuous digesters (labeled as P1 to P4) having a capacity of $36 \mathrm{~L}$ and working volume of $28 \mathrm{~L}$ were initially loaded with $22 \mathrm{~L}$ of diluted fresh cow dung (dilution ratio of 1:1) as a starter (source of bacteria) and were left until stable condition. When the biogas was produced, the prepared substrate was added daily into the respective digester at a loading rate of 500 $m L . d^{-1}$. Parameters to be observed included daily temperature and $\mathrm{pH}$ of the substrate, daily biogas production, TS and VS content, and biogas quality. The results showed that the digester worked at average $\mathrm{pH}$ of 6.9 and the daily temperature 26.3 to $29.7^{\circ} \mathrm{C}$. The total biogas production for 60 days was 608.4, 676.8, 600.0, and 613.3 L, respectively for P1, P2, P3, and P4. Biogas yield after the

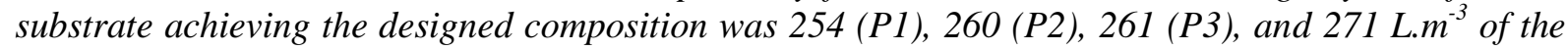
substrate (P4). The addition of elephant grass up to $50 \%$ could maintain high production of biogas.

Keywords: biogas; cow dung; elephant grass; productivity; semi-continuous

\section{A B S T R A K}

Penelitian ini bertujuan untuk mengetahui pengaruh komposisi substrat terhadap produktivitas biogas dari campuran kotoran sapi dan rumput gajah pada digester semi kontinu. Rumput gajah dan kotoran sapi segar diperoleh dari Jurusan Peternakan, Fakultas Pertanian, Universitas Lampung. Rumput gajah dipotong menggunakan pisau dan dihancurkan dengan blender hingga halus dan dicampurkan dengan kotoran sapi pada perbandingan berat padatan kering (TS) 35:65 (P1), 40:60 (P2), 45:55 (P3), dan 50:50 (P4). Campuran ini diencerkan dengan air hingga kandungan TS mencapai 5\% dan digunakan sebagai substrat. Empat digester semi kontinu (diberi label P1 hingga P4) dengan volume kerja $28 \mathrm{~L}$ mula-mula diisi dengan $22 \mathrm{~L}$ starter kotoran sapi segar yang diencerkan dengan air pada perbandingan berat 1:1 dan dibiarkan hingga stabil. Setelah gas mulai diproduksi, substrat yang telah dipersiapkan (sesuai label) ditambahkan ke dalam masing-masing digester dengan laju pembebanan $500 \mathrm{~mL}$ hari $^{-1}$. Parameter yang diamati meliputi suhu harian, $\mathrm{pH}$ substrat, kandungan TS dan VS, produksi biogas, dan kualitas biogas. Hasil penelitian menunjukkan bahwa digester bekerja pada $\mathrm{pH}$ rata-rata 6,9 dan suhu harian antara $26,3-29,7^{\circ} \mathrm{C}$. Total produksi biogas selama 60 hari adalah 
608,4; 676,8; 600,0; dan 613,3 L berturut-turut untuk P1, P2, P3, dan P4. Produktivitas biogas setelah substrat mencapai komposisi yang direncanakan adalah 254 (P1), 260 (P2), 261 (P3), dan $271 \mathrm{~L} / \mathrm{m}^{-3}$ substrat (P4). Penambahan rumput gajah hingga 50\% masih menghasilkan biogas yang tinggi.

Kata kunci: biogas; kotoran sapi; produktivitas; rumput gajah; semi-kontinu

\section{Pendahuluan}

Seiring dengan peningkatan jumlah penduduk, kebutuhan energi di Indonesia juga mengalami peningkatan yang signifikan. Konsumsi energi akhir Indonesia meningkat dari 925.972 setara barrel minyak (SBM) pada tahun 2007 (MEMR, 2008) menjadi 1,226 juta SBM pada tahun 2016 (MEMR, 2017). Di lain pihak, pemenuhan energi masih mengandalkan sumber energi dari bahan bakar fosil yang ketersediaannya kian menipis. Oleh karena itu perlu dikembangkan energi non fosil atau energi terbarukan yang dapat dipakai sebagai alternatif.

Biogas merupakan sumber energi alternatif yang diperoleh melalui dekomposisi bahan organik oleh bakteri secara anaerob sehingga bersifat terbarukan (renewable). Teknologi biogas merupakan teknologi konversi energi yang mudah diaplikasikan, ramah lingkungan dan bahan bakunya mudah didapat. Salah satu keunggulan biogas adalah bahwa bahan baku (substrat) untuk menghasilkan biogas sangat beragam meliputi berbagai limbah pertanian secara luas (termasuk peternakan, perikanan, kehutanan) dan tanaman energi. Selain itu substrat biogas dapat dikembangkan secara lokal.

Rumput gajah (Pennisetum purpureum) merupakan salah satu jenis rumput unggul yang dapat dikembangkan sebagai tanaman energi melalui teknologi konversi biogas. Tanaman ini tumbuh subur di Indonesia dengan produksi tahunan mencapai 200 ton rumput segar per hektar (Rukmana, 2005). Menurut Sawasdee dan Nipon (2014), komposisi rumput gajah mengandung karbohidrat $30,9 \%$, protein $27,0 \%$, lemak $14,8 \%$, abu total $18,2 \%$, dan serat $9,1 \%$ (berat kering). Dari komposisi tersebut rumput gajah merupakan bahan baku yang baik untuk produksi biogas. Produksi dan kandungan bahan organik yang tinggi membuat rumput gajah layak dipakai sebagai bahan baku untuk menghasilkan biogas. Produksi biogas dari rumput gajah memerlukan sumber bakteri yang juga dapat dikembangkan secara lokal. Salah satu sumber bakteri yang biasa digunakan dalam menghasilkan biogas adalah kotoran sapi. Sapi mampu menghasilkan limbah lebih banyak dari hewan ternak lainnya. Di Indonesia, seekor sapi dapat menghasilkan kotoran segar rata-rata 7,28 kg/hari (Tangkas dan Trihadiningrum, 2016). Kotoran hewan lain seperti kotoran ayam dan kotoran babi juga dapat digunakan.

Hasil penelitian sebelumnya menggunakan digester tipe batch menunjukkan bahwa penambahan rumput gajah mampu memperpanjang lama waktu produksi biogas dari kotoran sapi (Haryanto dkk., 2018a). Penelitian menggunakan digester semi kontinu menunjukkan bahwa laju pembebanan (loading rate) dan rasio $\mathrm{C} / \mathrm{N}$ mempengaruhi produksi biogas dari campuran kotoran sapi dan rumput gajah (Haryanto dkk., 2017a). Selain itu, frekuensi pengumpanan substrat dari campuran kotoran sapi dan rumput gajah memengaruhi produksi dan kualitas biogas. Dalam penelitian produksi biogas dari campuran kotoran sapi dan rumput gajah (perbandingan padatan kering 3:1) dengan laju pembebanan 0,5 L.hari ${ }^{-1}$ menggunakan digester semi kontinu (volume kerja 25 L), Junaidi (2018) melaporkan bahwa frekuensi pengumpanan substrat dapat dilakukan sekali dalam empat hari. Perbandingan yang optimum antara kotoran sapi sebagai sumber bakteri dan rumput gajah sebagai sumber makanannya merupakan parameter penting untuk memperoleh produksi yang tinggi dan kualitas biogas yang baik. Penelitian ini bertujuan untuk mengetahui pengaruh komposisi substrat pada produksi biogas dari campuran kotoran sapi dan rumput gajah pada digester semi kontinu.

\section{Metode Penelitian}

Bahan utama yang digunakan dalam penelitian ini adalah kotoran sapi (KS) dan 
rumput gajah (RG) yang diperoleh dari Jurusan Peternakan, Fakultas Pertanian, Unila. Rumput gajah dipotong menggunakan pisau dengan panjang sekitar $2 \mathrm{~cm}$ lalu dihaluskan menggunakan blender dapur. Hal ini dilakukan untuk mempermudah bakteri dalam mendegradasi bahan organik rumput gajah, terutama pada fase hidrolisis. Herawati dan Wibawa (2010) melaporkan bahwa biogas dengan kadar metana tertinggi 64,78\% dihasilkan dari campuran sawi hijau dan jerami padi dalam bentuk serbuk dibandingkan jerami dipotong 0,5 $\mathrm{cm}$. Rumput gajah dicampur dengan kotoran sapi pada perbandingan berat padatan kering (TS) antara rumput gajah dengan kotoran sapi 35:65 (P1), 40:60 (P2), 45:55 (P3), dan 50:50 (P4).

\subsection{Produksi Biogas}

Proses produksi biogas dilakukan menggunakan digester semi kontinu (Gambar 1) sebagaimana dilaporkan sebelumnya (Haryanto dkk., 2018b).

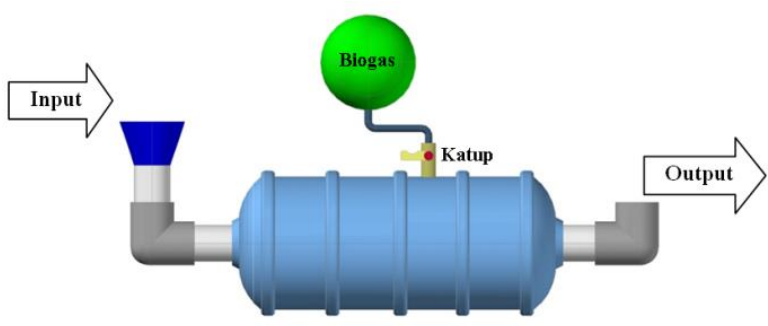

Gambar 1. Sistem digester semi kontinu $36 \mathrm{~L}$ dengan volume kerja 28 L

Dalam penelitian ini digunakan empat digester yang diberi label P1 hingga $\mathrm{P} 4$ dengan volume kerja masing-masing 28 liter. Sebagai starter (sumber bakteri) digunakan kotoran sapi yang diencerkan dengan air pada perbandingan berat 1:1. Mula-mula keempat digester diisi dengan starter masing-masing 22 liter dan dibiarkan beberapa hari untuk stabilisasi. Digester dibiarkan beberapa hari sampai ada tanda dihasilkan biogas. Apabila biogas telah dihasilkan maka ditambahkan substrat yang sudah disiapkan dengan laju pembebanan 500 mL.hari ${ }^{-1}$ pada keempat digester sesuai dengan komposisi campuran yang direncanakan. Skala waktu diperhitungkan sejak pembebanan 500 mL.hari ${ }^{-1}$ ini dilakukan. Dengan volume kerja 28
L, maka diperlukan waktu selama 56 hari agar substrat di dalam digester mencapai komposisi yang direncanakan (P1-P4).

\subsection{Analisis dan Perhitungan}

Pengamatan yang dilakukan meliputi kadar air (KA), total solid (TS), volatile solid (VS), rasio $\mathrm{C} / \mathrm{N}$, produksi biogas, produktivitas biogas, dan kualitas biogas. Parameter proses yang diamati meliputi $\mathrm{pH}$, suhu digester, dan suhu udara lingkungan. Kadar air bahan diukur menggunakan metode gravimetri dengan cara mengeringkan bahan di dalam oven (Memmert, type UM 500, Germany) pada suhu $105{ }^{\circ} \mathrm{C}$ selama 24 jam. Kadar air (KA) dan TS dihitung menggunakan Persamaan (2):

$$
\begin{aligned}
& \mathrm{KA}=100 \% \times\left(W_{1}-W_{2}\right) / W_{1} \\
& \mathrm{TS}=100-\mathrm{KA}
\end{aligned}
$$

dengan $W_{1}$ adalah massa bahan basah dan $W_{2}$ adalah massa bahan kering ( $\mathrm{g}$ ).

Volatile solid diukur dengan cara membakar sampel di dalam tanur (Barnstead Thermolyne FB1300, USA) selama 2 jam pada suhu $550{ }^{\circ} \mathrm{C}$. Kadar abu dan kadar VS dinyatakan dalam \% TS dan dihitung dari Persamaan (3) dan (4). Komponen organik yang mengalami dekomposisi dinyatakan dengan penyisihan VS atau VS removal $\left(\mathrm{VS}_{\mathrm{r}}\right)$ dan dihitung dari Persamaan (5).

$$
\begin{aligned}
\mathrm{Abu} & =100 \%\left(W_{3}-W_{4}\right) / W_{3} \\
\mathrm{VS} & =100-\mathrm{Abu} \\
\mathrm{VS}_{\mathrm{r}} & =100 \%\left(\mathrm{VS}_{\text {input }}-\mathrm{VS}_{\text {output }}\right) / \mathrm{VS}_{\text {input }}
\end{aligned}
$$

dengan $W_{1}$ adalah massa bahan kering sebelum diabukan (g) dan $W_{4}$ adalah massa bahan setelah pengabuan $(\mathrm{g}) . \mathrm{VS}_{\text {input }}$ dan $\mathrm{VS}_{\text {output }}$ berturut-turut adalah massa (g) komponen padatan volatil substrat masuk ke dalam digester dan substrat keluar dari digester.

Kadar karbon (C) dan nitrogen $(\mathrm{N})$ diukur menggunakan elemental analyzer (Elementar Vario EL Cube, Germany). Rasio C/N campuran substrat dihitung menggunakan Persamaan (6).

$$
C / N=\frac{\left(C_{\mathrm{ks}} \times m_{\mathrm{ks}}\right)+\left(C_{\mathrm{rg}} \times m_{\mathrm{rg}}\right)}{\left(N_{\mathrm{ks}} \times m_{\mathrm{ks}}\right)+\left(N_{\mathrm{r}} \times m_{\mathrm{rg}}\right)}
$$


dengan $m$ adalah massa kering bahan engan subskrip $k s$ untuk kotoran sapi dan $r g$ untuk rumput gajah.

\section{Hasil dan Pembahasan}

\subsection{Karakteristik Substrat}

Karakteristik substrat yang digunakan pada penelitian ini diberikan dalam Tabel 1. Dalam Tabel 1, jumlah campuran substrat adalah 500 gram yaitu banyaknya substrat yang ditambahkan ke dalam setiap digester setiap hari. Karakteristik substrat seperti rasio $\mathrm{C} / \mathrm{N}$, kandungan TS, dan VS sangat mempengaruhi pembentukan biogas. Selama proses dekomposisi anaerobik, pada umumnya bakteri menggunakan karbon 25-30 lebih cepat dibandingkan nitrogen (Yadvika dkk., 2004). Oleh karena itu, untuk memenuhi kebutuhan ini mikroba memerlukan rasio $\mathrm{C} / \mathrm{N}$ antara 20-30 (Marchaim, 1992). Rasio C/N yang tinggi akan menimbulkan konsumsi nitrogen yang cepat oleh metanogen, mengakibatkan kekurangan nitrogen yang penting dalam formasi protein sehingga produksi gas menjadi rendah. Di lain pihak, rasio $\mathrm{C} / \mathrm{N}$ yang rendah mengakibatkan akumulasi ammonia dan nilai $\mathrm{pH}$ melebihi 8,5, yang merupakan kondisi toksik bagi metanogen sehingga gas yang dihasilkan juga rendah
(Deublein dan Steinhauser, 2008). Pada Tabel 1 terlihat bahwa rasio $\mathrm{C} / \mathrm{N}$ dari substrat pada empat perlakuan komposisi campuran praktis tidak memiliki perbedaan. Rasio C/N substrat pada P1 hingga P4 memilki rentang nilai 29,13 hingga 29,53. Hal ini terjadi karena nilai rasio $\mathrm{C} / \mathrm{N}$ kotoran sapi $(28,03)$ tidak jauh berbeda dari nilai rasio $\mathrm{C} / \mathrm{N}$ rumput gajah $(30,67)$ sehingga campurannya akan memiliki rasio $\mathrm{C} / \mathrm{N}$ dengan kisaran yang sempit. Nilai rasio $\mathrm{C} / \mathrm{N}$ ini masih berada dalam kisaran yang optimum untuk proses produksi biogas.

\subsection{Periode Start-up}

Periode start-up merupakan waktu yang dibutuhkan bakteri untuk siap mengurai bahan organik sehingga terbentuk biogas di dalam digester. Waktu start-up pada masing-masing digester berbeda, karena bakteri perlu beradaptasi pada lingkungan digester. Dalam penelitian ini, periode start-up dihitung dari awal pengisian digester dengan starter $22 \mathrm{~L}$ sampai biogas dihasilkan pertama kali. Periode start-up pada semua perlakuan hampir sama, yaitu 8 hari untuk perlakuan P1, P3 dan $\mathrm{P} 4$, dan 10 hari untuk perlakuan P2.

Tabel 1. Komposisi dan karakteristik substrat campuran rumput gajah dan kotoran sapi

\begin{tabular}{|c|c|c|c|c|c|c|c|c|}
\hline Perlakuan & Bahan & $\begin{array}{c}\text { Jumlah } \\
\text { (g) }\end{array}$ & $\begin{array}{l}\text { KA } \\
(\%)\end{array}$ & $\begin{array}{c}\mathrm{C} \\
(\%)\end{array}$ & $\begin{array}{c}\mathrm{N} \\
(\%)\end{array}$ & $\begin{array}{c}\text { Rasio } \\
\mathrm{C} / \mathrm{N}\end{array}$ & $\begin{array}{l}\text { TS } \\
(\%)\end{array}$ & $\begin{array}{c}\mathrm{VS} \\
(\% \mathrm{TS})\end{array}$ \\
\hline \multirow{4}{*}{ P1 (35:65) } & Kotoran sapi & 96 & 82,90 & 39,87 & 1,42 & 28,08 & 17,10 & 88,33 \\
\hline & Rumput gajah & 45 & 80,75 & 55,51 & 1,81 & 30,67 & 19,25 & 90,85 \\
\hline & Air & 359 & 100 & 0 & 0 & 0 & 0 & 0 \\
\hline & Campuran & 500 & 95 & 45,35 & 1,56 & 29,13 & 5 & 89,21 \\
\hline \multirow[t]{4}{*}{ P2 (40:60) } & Kotoran sapi & 88 & 82,90 & 39,87 & 1,42 & 28,08 & 17,10 & 88,33 \\
\hline & Rumput gajah & 52 & 80,75 & 55,51 & 1,81 & 30,67 & 19,25 & 90,85 \\
\hline & Air & 360 & 100 & 0 & 0 & 0 & 0 & 0 \\
\hline & Campuran & 500 & 95 & 46,13 & 1,58 & 29,27 & 5 & 89,34 \\
\hline \multirow[t]{4}{*}{ P3 (45:55) } & Kotoran sapi & 81 & 82,90 & 39,87 & 1,42 & 28,08 & 17,10 & 88,33 \\
\hline & Rumput gajah & 58 & 80,75 & 55,51 & 1,81 & 30,67 & 19,25 & 90,85 \\
\hline & Air & 361 & 100 & 0 & 0 & 0 & 0 & 0 \\
\hline & Campuran & 500 & 95 & 46,91 & 1,60 & 29,40 & 5 & 89,46 \\
\hline \multirow[t]{4}{*}{ P4 (50:50) } & Kotoran sapi & 73 & 82,90 & 39,87 & 1,42 & 28,08 & 17,10 & 88,33 \\
\hline & Rumput gajah & 65 & 80,75 & 55,51 & 1,81 & 30,67 & 19,25 & 90,85 \\
\hline & Air & 362 & 100 & 0 & 0 & 0 & 0 & 0 \\
\hline & Campuran & 500 & 95 & 47,69 & 1,62 & 29,53 & 5 & 89,59 \\
\hline
\end{tabular}


Periode start up ini tidak diperhitungkan dalam skala waktu produksi biogas. Lamanya periode start-up ini mungkin disebabkan oleh kualitas kotoran sapi yang kurang baik. Menurut Pandey dkk. (2013) periode start-up bisa berlangsung 1-3 minggu.

\subsection{Derajat Keasaman}

Gambar 2 menunjukkan $\mathrm{pH}$ substrat di dalam digester selama 60 hari pengamatan. Setiap digester memiliki $\mathrm{pH}$ rata-rata hampir sama yaitu 6,9. Hal ini menunjukkan $\mathrm{pH}$ proses mendekati netral dan merupakan kondisi yang baik untuk kehidupan bakteri. Gambar 2 memperlihatkan seiring dengan berjalannya waktu, substrat yang pada awalnya cenderung asam dengan nilai $\mathrm{pH}$ 6,4 (P4), 6,5 (P1 dan P3), dan 6,6 (P2), berubah ke arah netral. Mulai hari ke-4 hingga hari ke-32 praktis semua digester memiliki kisaran $\mathrm{pH}$ antara 6,7 hingga 7,0, kecuali P1 yang sempat memiliki pH 7,1 pada hari ke-19. Dengan bertambahnya hari, digester makin stabil dan mulai hari ke-33 semua digester memiliki kisaran pH antara 6,9 hingga 7,1. Simamora dkk. (2006) menyebutkan digester dengan $\mathrm{pH}$ 6,8-7,8 merupakan kondisi yang optimum bagi kehidupan bakteri anaerobik. Faktor pH sangat berperan dalam dekomposisi anarerob karena pada rentang $\mathrm{pH}$ yang tidak sesuai, bakteri tidak dapat tumbuh dengan maksimal dan bahkan dapat menyebabkan kematian, sehingga dapat memengaruhi produksi gas metana. Menurut Marchaim (1992) kelompok metanogenik adalah yang paling sensitif terhadap $\mathrm{pH}$. Rendahnya $\mathrm{pH}$ dapat menyebabkan rantai reaksi biologi terhenti. Pada umumnya produksi biogas akan tinggi pada pH $\quad$ sekitar 7 (netral). Pada kondisi ini mikroorganisme mampu mengurai bahan organik secara maksimal, sehingga menghasilkan produksi biogas yang tinggi. Fachry dkk. (2004) juga menunjukkan bahwa semakin $\mathrm{pH}$ mendekati netral maka semakin tinggi kadar $\mathrm{CH}_{4}$ yang berarti kualitas biogas makin baik.

\subsection{Temperatur}

Temperatur sangat berpengaruh terhadap aktivitas mikroorganisme yang akan mengurai bahan organik. Gambar 3 menunjukkan temperatur digester selama 60 hari pengamatan (pagi dan sore). Suhu digester tidak jauh berbeda dengan suhu udara lingkungan (ambient), baik pagi maupun sore hari. Menurut Junaidi (2018) rata-rata suhu digester tidak jauh berbeda karena digester diletakkan di dalam ruangan sehingga tidak terpapar langsung oleh cahaya matahari.

Dalam penelitian ini, semua digester bekerja pada kisaran suhu mesofilik. Temperatur rata-rata pada sore hari $\left(29,6-29,7^{\circ} \mathrm{C}\right)$ lebih tinggi $3,2-3,3$ ${ }^{\circ} \mathrm{C}$ dibandingkan temperatur pada pagi hari $\left(26,3-26,4{ }^{\circ} \mathrm{C}\right)$. Tetapi pada hari ke-50 dan hari ke-55 suhu pada sore hari turun cukup jauh hingga nilainya kurang dari suhu pada pagi hari. Hal ini disebabkan pada hari tersebut terjadi hujan di sore hari sehingga suhu udara menjadi dingin.

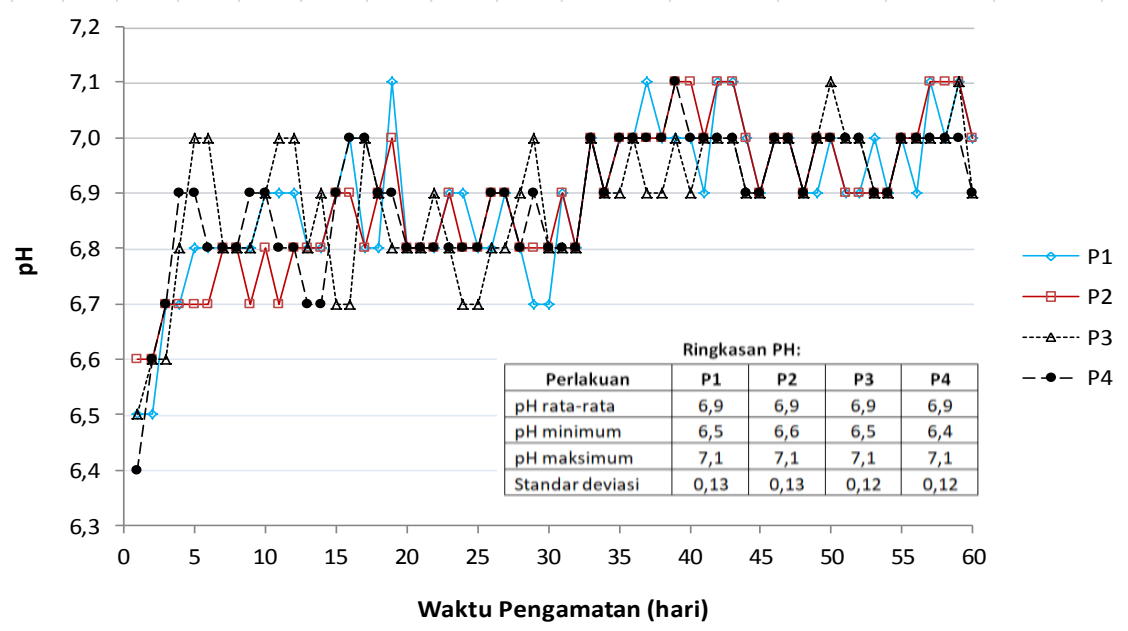

Gambar 2. Perkembangan pH harian substrat di dalam digester (P1 - P4) selama 60 hari pengamatan 
Tabel 2. Efisiensi digester dalam bentuk penyisihan VS $\left(\mathrm{VS}_{\mathbf{r}}\right)$

\begin{tabular}{ccccccccc}
\hline Perlakuan & $\mathrm{VS}_{\text {in }}(\% \mathrm{TS})$ & $\mathrm{VS}_{\text {in }}(\mathrm{g})$ & $\mathrm{TS}_{\text {out }}(\%)$ & $\mathrm{TS}_{\text {out }}(\mathrm{g})$ & $\mathrm{VS}_{\text {out }}(\% \mathrm{TS})$ & $\mathrm{VS}_{\text {out }}(\mathrm{g})$ & $\mathrm{VS}_{\mathrm{r}}(\mathrm{g})$ & $\mathrm{VS}_{\mathrm{r}}(\%)$ \\
\hline P1 & 89,21 & 22,30 & 3,19 & 15,95 & 73,69 & 11,75 & 11,34 & 49,10 \\
P2 & 89,34 & 22,33 & 3,40 & 17,00 & 73,88 & 12,56 & 9,48 & 43,01 \\
P3 & 89,46 & 22,37 & 2,36 & 11,80 & 73,43 & 8,66 & 13,92 & 61,63 \\
P4 & 89,59 & 22,40 & 3,06 & 15,30 & 76,23 & 11,66 & 9,86 & 45,80 \\
\hline
\end{tabular}

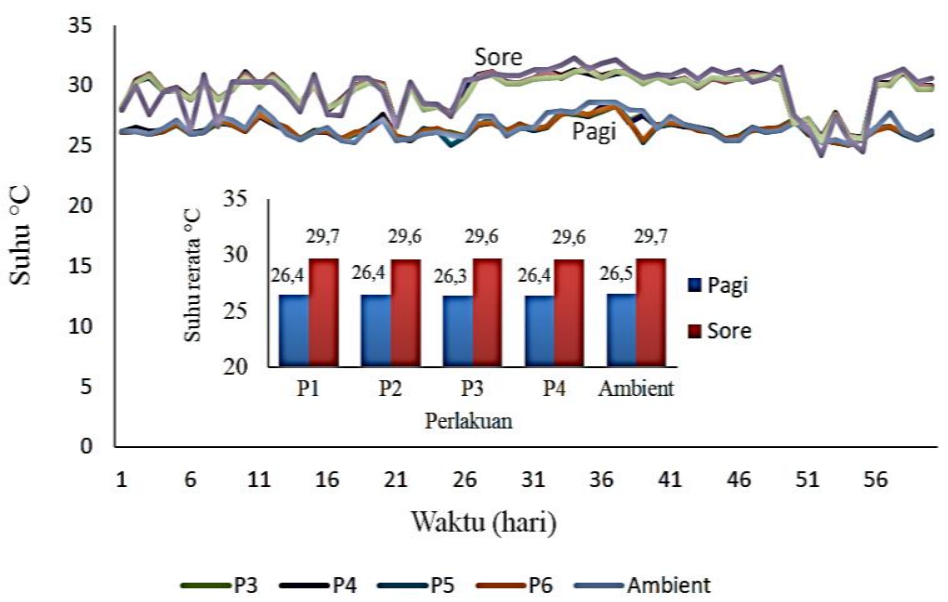

Gambar 3. Temperatur harian digester (P1 - P4) dan udara ambient pada pagi dan sore hari serta temperatur ratarata selama 60 hari pengamatan.

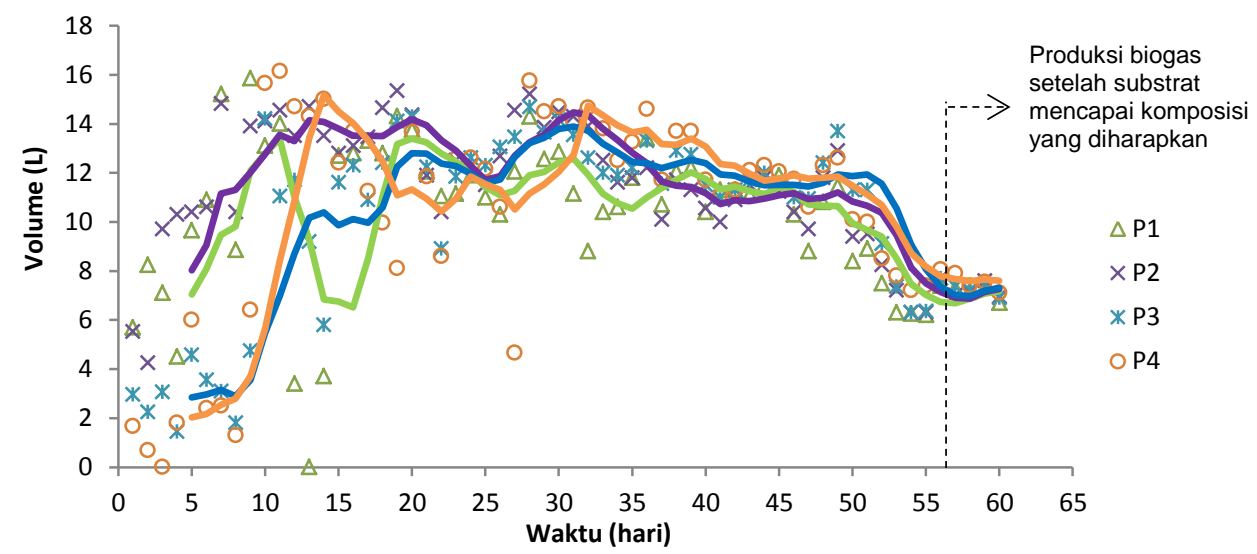

Gambar 4. Produksi biogas harian (simbol) dan produksi biogas rata-rata (moving average) 5-harian (garis)

Dalam tahap pembentukan metana, suhu lingkungan maupun suhu di dalam digester memiliki pengaruh yang signifikan. Suhu digester berpengaruh pada proses dekomposisi anaerobik dari bahan organik, semakin tinggi temperatur optimum bakteri maka aktivitas mikroorganisme juga semakin meningkat (Kaparaju, 2006). Afta (2014) mengamati bahwa bakteri metanogenik sangat sensitif terhadap perubahan suhu dan penurunan $1-2^{\circ} \mathrm{C}$ dapat menurunkan produksi biogas secara signifikan.

\subsection{Penyisihan VS (VS removal)}

Volatile solid merupakan sumber makanan bagi bakteri non metanogen yang bekerja pada tahap awal proses biogas. Substrat dengan kandungan VS tinggi akan menghasilkan biogas lebih banyak (Widarti dkk., 2012). Penyisihan VS atau VS removal $\left(\mathrm{VS}_{\mathrm{r}}\right)$ menunjukkan di dalam digester terjadi proses degradasi senyawa organik. Semakin besar penyisihan VS maka semakin banyak bahan organik yang dicerna oleh mikroorganisme sehingga semakin banyak pula biogas yang dihasilkan. Pada penelitian ini VS 
removal berkisar antara 43,0\% hingga 61,6\% seperti terlihat pada Tabel 2.

Penyisihan VS dapat dianggap sebagai kemampuan atau efisiensi digester dalam merombak atau mendekompoisisi bahan organik. Efisiensi digester yang diperoleh pada penelitian ini $(43,0-61,6 \%)$ tidak jauh berbeda dengan hasil-hasil penelitian sebelumnya baik pada disgester skala laboratorium sebesar 42,1-46,4\% (Haryanto dkk.., 2018b), maupun digester skala rumah tangga di lapangan sebesar 43,3-58,0\% (Haryanto dkk., 2017b).

\subsection{Produksi Biogas}

Gambar 4 memperlihatkan produksi biogas harian selama 60 hari pengamatan dari keempat digester dengan komposisi substrat yang berbeda. Dalam gambar tersebut juga ditampilkan produksi biogas rata-rata harian menggunakan metode moving average 5-harian yang disajikan dalam bentuk plot garis pada Gambar 4. Selain itu di dalam Gambar 4 juga diberikan batas ketika substrat telah mencapai komposisi yang direncanakan, yaitu 35:65, 40:60, 45:55, dan 50:50 (rumput gajah dibanding kotoran sapi).

Gambar 4 menujukkan bahwa produksi biogas mula-mula rendah, lalu naik hingga mencapai produksi sekitar 14 L.hari ${ }^{-1}$ mulai hari ke-10. Meskipun ada sedikit kecenderungan penurunan, produksi biogas masih tinggi hingga sekitar satu bulan kemudian. Mulai hari ke-50 hingga hari ke-56 produksi biogas turun cukup tajam dari sekitar $12 \mathrm{~L}$ hingga sekitar $7 \mathrm{~L}$ untuk semua perlakuan komposisi substrat. Penurunan ini mungkin disebabkan oleh karena makin meningkatnya komponen rumput gajah di dalam substrat. Menurut Rekha dan Aniruddha (2013) rumput gajah mengandung makro molekul yang kompleks sehingga sulit untuk didegradasi secara langsung oleh mikroorganisme. Mulai hari ke-56 ketika campuran substrat telah mencapai komposisi yang direncanakan, produksi biogas berkisar antara 7-8 L.

Gambar 5 menunjukkan produksi biogas kumulatif selama 60 hari pengamatan. Dalam hal ini, hari pertama adalah hari digester menghasilkan biogas (bukan hari pertama pengisian starter). Pada penelitian ini P2 (komposisi 40:60) menghasilkan total biogas yang paling tinggi $(676,76$ L) dibandingkan dengan P1 (608,44 L), P3 (600,02 L), dan P4 $(613,27$ L). Hal ini menunjukkan bahwa komposisi substrat berpengaruh terhadap produksi biogas.

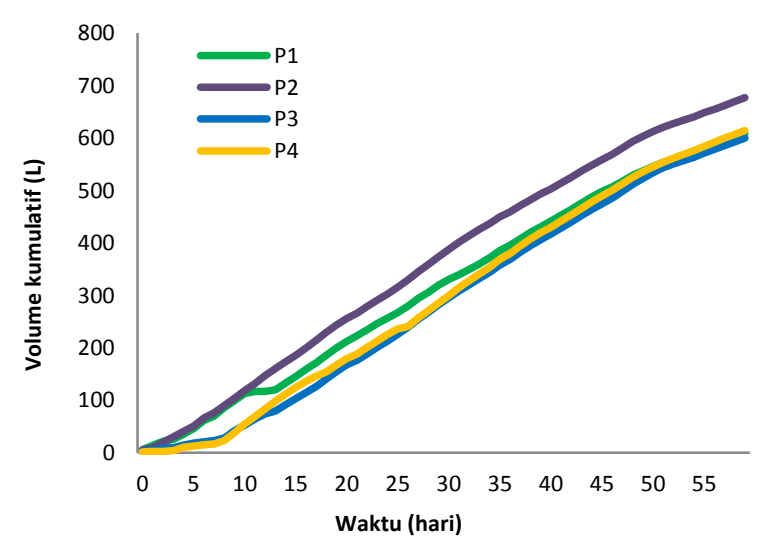

Gambar 5. Produksi biogas kumulatif dari campuran kotoran sapi dan rumput gajah pada empat komposisi yang berbeda (P1 - P4)

\subsection{Produktivitas Biogas}

Tabel 3 menunjukkan produksi dan produktivitas biogas setelah substrat di dalam digester mencapai komposisi yang direncanakan (mulai hari ke-56). Hasil penelitian menunjukkan bahwa produksi biogas harian rata-rata dari keempat kompoisisi substrat tidak menunjukkan perbedaan yang nyata, berkisar antara 7,18 $\pm 0,28$ $\mathrm{L}(\mathrm{P} 1)$ hingga $7,60 \pm 0,38 \mathrm{~L}$ (P4). Hal ini mengindikasikan bahwa rumput gajah dapat ditambahkan sebagai campuran substrat pada produksi biogas dari kotoran sapi hingga 50\% (basis kering).

Tabel 3. Produktivitas biogas setelah substrat mencapai komposisi yang direncanakan

\begin{tabular}{cccccc}
\hline Perlakuan & $\begin{array}{c}\text { Produksi Biogas } \\
\left(\mathrm{L} . h a r i^{-1}\right)\end{array}$ & $\begin{array}{c}\mathrm{VS}_{\mathrm{r}} \\
(\mathrm{kg})\end{array}$ & Vol. Kerja $(\mathrm{L})$ & $\begin{array}{c}\text { Produktivitas biogas } \\
(\mathrm{L})\left(\mathrm{g} \mathrm{VS}_{\mathrm{r}}\right)^{-1}\end{array}$ & $(\mathrm{~L}) /\left(\text { hari.m }{ }^{3} \text { substrat }\right)^{-1}$ \\
\hline P1 & $7,18 \pm 0,28$ & 0,0113 & 28 & $633 \pm 24,56$ & $254 \pm 9,91$ \\
P2 & $7,27 \pm 0,35$ & 0,0095 & 28 & $767 \pm 31,23$ & $260 \pm 12,60$ \\
P3 & $7,31 \pm 0,29$ & 0,0139 & 28 & $525 \pm 25,88$ & $261 \pm 10,44$ \\
P4 & $7,60 \pm 0,38$ & 0,0099 & 28 & $771 \pm 33,84$ & $271 \pm 13,66$ \\
\hline
\end{tabular}


Produktivitas biogas dinyatakan dalam dua hal, yaitu produksi biogas harian per satuan volume substrat dan produksi biogas harian per satuan komponen bahan organik yang terdegradasi $\left(\mathrm{VS}_{\mathrm{r}}\right)$. Pada digester sistem semi kontinu produktivitas sangat dipengaruhi oleh total produksi biogas yang dihasilkan dan banyaknya bahan organik yang terdegradasi oleh bakteri. Hasil perhitungan juga menunjukan produktivitas biogas per satuan volume substrat tidak menunjukkan perbedaan signifikan, dalam kisaran $254 \pm 9,91(\mathrm{~L})\left(\mathrm{m}^{3} \text {.hari }\right)^{-1}$ hingga $271 \pm$ 13,66 $(\mathrm{L})\left(\mathrm{m}^{3} \text {.hari }\right)^{-1}$. Tetapi, produktivitas biogas per satuan $\mathrm{VS}_{\mathrm{r}}$ menunjukkan perbedaan dengan komposisi P4 (50:50) dan komposisi P2 (40:60) menghasilkan produktivitas tertinggi, masingmasing adalah $771 \pm 33,84$ dan $767 \pm 31,23 \mathrm{~L}(\mathrm{~kg}$ $\left.\mathrm{VS}_{\mathrm{r}}\right)^{-1}$. Pada penelitian ini produksi biogas per satuan masa bahan organik yang terdekomposisi cukup tinggi. Tetapi, bila dilihat dari produksi biogas per satuan volume substrat masih tergolong rendah, yaitu antara 254 L-biogas. $\mathrm{m}^{-3}$ substrat pada P1 hingga 271 L-biogas. $\mathrm{m}^{-3}$ substrat pada P4. Produksi biogas per satuan volume substrat adalah 271, 261, 260 dan 256 L.m ${ }^{-3}$, berturut-turut untuk komposisi substrat (rumput gajah:kotoran sapi) 50:50, 45:55, 40:60, dan 35:65. Sebelumnya kami melaporkan bahwa produksi biogas per satuan volume substrat bisa

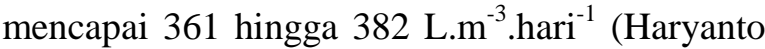
dkk., 2017b). Hal ini menunjukkan bahwa tidak semua bahan organik yang terdekomposisi menghasilkan biogas, dan sebagian mungkin masih menjadi asam. Rumput lebih sulit terdegradasi sehingga proses metanisasi memerlukan waktu lebih panjang.

\subsection{Kualitas Biogas}

Kandungan metana $\left(\mathrm{CH}_{4}\right)$ yang tinggi merupakan salah satu indikator keberhasilan proses fermentasi pada biogas. Biogas berkualitas baik terdiri dari metana sekitar $55-70 \%$ diikuti oleh karbon dioksida sekitar 30-45\%. Pada penelitian kualitas biogas diamati dengan cara membakar biogas dan mengamati nyala api yang dihasilkan. Biogas dengan kandungan $\mathrm{CH}_{4}$ yang tinggi akan memberikan nyala api biru yang besar. Pada hari-hari awal, biogas yang dihasilkan tidak bisa dibakar. Hal ini menandakan kandungan $\mathrm{CH}_{4}$ masih rendah dan biogas masih didominasi oleh $\mathrm{CO}_{2}$. Biogas dapat dibakar untuk yang pertama kali pada hari ke-15 (P1 dan P3), ke-19 (P2), dan ke-20 (P4). Meskipun demikian, nyala api masih kecil dan belum bisa membesar. Bahkan jika laju aliran biogas dinaikkan pada saat dinyalakan, maka nyala api justru akan mati. Gambar 6 memperlihatkan perkembangan kualitas nyala api biogas.

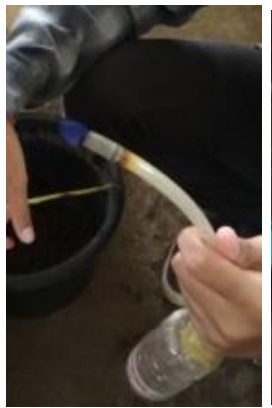

(a)

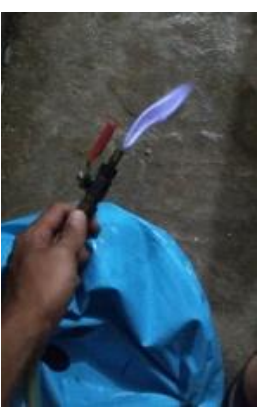

(b)

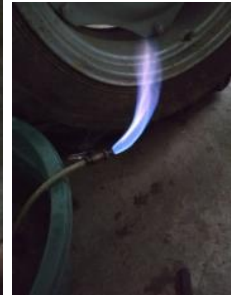

(c)
Gambar 6. Perkembangan nyala biogas dari hari ke-15 (a), hari ke-18 (b), hingga hari ke-43 (c)

Pada Gambar 6 terlihat bahwa nyala api yang kecil saat pertama biogas bisa dibakar (hari ke15) menjadi makin besar (hari ke-18) dan kurang lebih satu bulan kemudian memberikan nyala api yang besar. Hal ini menunjukkan bahwa kandungan metana telah tinggi. Menurut Uwar dkk. (2012) kadar $\mathrm{CO}_{2}$ berpengaruh terhadap pembakaran $\mathrm{CH}_{4}$. Pembakaran bahan bakar tanpa $\mathrm{CO}_{2}$ akan menghasilkan api berwarna biru sedangkan api berwarna kuning kemerahan menunjukan bahwa kadar $\mathrm{CO}_{2}$ yang terkandung dalam biogas cukup tinggi. Ihsan (2013) menyatakan bahwa uji nyala yang menghasilkan warna biru menunjukkan adanya unsur metana di dalam biogas dan diperkirakan memiliki kandungan metana dalam gas sekitar $45 \%$. Junaedi (2018) melaporkan bahwa kandungan metana pada biogas yang dihasilkan dari rumput gajah mencapai 51,8\% setelah kurang lebih 2 bulan sejak pengisian substrat.

\section{Kesimpulan}

Rumput gajah berpotensi sebagai campuran pada substrat dalam pembuatan biogas. Dengan 
menggunakan kotoran sapi sebagai sumber bakteri, rumput gajah dapat dicampurkan hingga perbandingan berat TS 50:50. Meskipun produksi biogas total tertinggi dihasilkan dari substrat dengan komposisi campuran rumput gajah dan kotoran sapi 40:60, tetapi setelah substrat mencapai komposisi yang sesungguhnya, semua perlakuan menghasilkan produksi biogas rata-rata harian yang tidak berbeda secara signifikan dalam kisaran antara 7,18 \pm 0,28 L hingga 7,60 \pm $0,38 \mathrm{~L}$. Produksi biogas harian per satuan volume kerja digester juga tidak menunjukkan perbedaan signifikan dalam kisaran $254 \pm 9,91$ $(\mathrm{L})\left(\mathrm{m}^{3} \text {.hari }\right)^{-1}$ hingga $271 \pm 13,66(\mathrm{~L})\left(\mathrm{m}^{3} \cdot \text { hari }\right)^{-1}$. Perlakuan P4 (komposisi substrat 50:50) menghasilkan produktivitas biogas per satuan VS removal sebesar $771 \pm 33,84(\mathrm{~L})\left(\mathrm{kg} \mathrm{VS}_{\mathrm{r}}\right)^{-1}$.

\section{Ucapan Terimakasih}

Penelitian ini didanai dari penelitian Skim STRANAS tahun 2017 dengan nomor kontrak 071/SP2H/LT/DRPM/IV/2017585.

\section{Daftar Pustaka}

Afta, T., Iqbal, J., Iqbal, K., Aslam, S., and Ahmad, R., 2014, Production of biogas from an agro-industrial waste and its characteristics, J. Sci. Res., 6 (2), 347-357

Deublein, D., and Steinhauser, A., 2008, Biogas from Waste and Renewable Resource, WileyVCH Verlag GmbH \&Co. KgaA, Weinheim

Fachry, H. A. R., Rinenda, dan Gustiawan, 2004, Penentuan nilai kalorifik yang dihasilkan dari proses pembentukan biogas, Jurnal Teknik Kimia, 2 (5), 7-12

Haryanto, A., Hasanudin, U., Afrian, C., and Zulkarnaen, I., 2018a, Biogas production from anaerobic codigestion of cowdung and elephant grass (Pennisetum purpureum) using batch digester, IOP Conf. Series: Earth and Environmental Science, 141, 012011

Haryanto, A., Sugara, B. P., Telaumbanua, M., and Rosadi, R. A. B., 2018b, Anaerobic codigestion of cow dung and rice straw to produce biogas using semi-continuous flow digester: Effect of urea addition, IOP Conf.
Series: Earth and Environmental Science, 147, 012032

Haryanto, A., Candra, P. A., Suharyatun, S., Rahmawati, W., Hasanudin, U., and Triyono, S., 2017a, Effect of loading rate and urea addition on biogas yield using semicontinuous flow anaerobic codigestion of cowdung and elephant grass (Penisetum purpuerum), International Conference on Food Security Innovation (ICFSI), Banten, October 18-20, 2017

Haryanto, A., Cahyani, D., Triyono, S., Murdapa, F., and Haryono, D., 2017b, Economic benefit and greenhouse gas emission reduction potential of a family-scale cowdung anaerobic biogas digester, Int. Journal of Renewable Energy Development, 6 (1), 29-36

Herawati, D. A., dan Wibawa, A. A., 2010, Pengaruh pretreatment jerami padi pada produksi biogas dari jerami padi dan sampah sayur sawi hijau secara batch, Jurnal Rekayasa Proses, 4 (1), 25-29

Ihsan, A., Bahri, S., dan Musafira, 2013, Produksi biogas menggunakan cairan isi rumen sapi dengan limbah cair tempe, Natural Science: Journal of Science and Technology, 2 (2), 27-35

Junaidi, A, 2018, Pengaruh Frekuensi Pengumpanan Terhadap Produksi dan Kualitas Biogas dari Campuran Kotoran Sapid dan Rumput Gajah (Pennisetum purpureum) pada Digester Semi Kontinyu (Skripsi), Jurusan Teknik Pertanian, Fakultas Pertanian, Universitas Lampung, Bandar Lampung

Kaparaju, P., 2007, Effect of temperature and active biogas process on passive separation of digested manure, Bioresour. Technol., 99 (5), 1345-1352

Marchaim, U., 1992, Biogas Processes for Sustainable Development, FAO, Rome.

MEMR (Ministry of Energy and Mineral Resources), 2008, Handbook of Energy \& Economic Statistics of Indonesia

MEMR (Ministry of Energy and Mineral Resources), 2017, Handbook of Energy \& Economic Statistics of Indonesia 2017 
Pandey, P. K., Ndegwa, P. M., Soupir, M. L., Alldredge, J. R., and Pitts, M.J., 2013, Efficacies of inocula on the startup of anaerobic reactors treating dairy manure under stirred and unstirred conditions, Biomass and Bioenergy, 35, 2705-2720

Rekha, B. N., and Aniruddha, B. P., 2013, Performance enhancement of batch anaerobic digestion of napier grass by alkali pretreatment, International Journal of ChemTech Research, 5 (2), 558-564

Rukmana, H.R., 2005, Budidaya Rumput Unggul, Kanisius, Yogyakarta

Sawasdee, S., and Nipon, P., 2014, Feasibility of biogas production from napier grass, Energy Procedia, 61, 1229 - 1233

Simamora, S., Salundik, Wahyuni, S., dan Surajudin, 2006, Membuat Biogas Pengganti Minyak dan Gas Dari Kotoran Ternak, Agromedia Pustaka, Jakarta
Tangkas, G. P., dan Trihadiningrum, Y., 2016, Kajian pengelolaan limbah padat peternakan sapi Simantri berbasis 2R (reduce dan recycle) di Kecamatan Seririt, Kabupaten Buleleng, Jurnal Teknik ITS, 5 (2), D86-D91

Uwar, N. A., Wardana, I. N. G, dan Widhiyanuriawan, D., 2012, Karakteristik pembakaran $\mathrm{CH}_{4}$ dengan penambahan $\mathrm{CO}_{2}$ pada model Helle-Shaw Cell pada penyalaan bawah, Jurnal Rekayasa Mesin, 3 (1), 249-257

Widarti, B. N., Syamsiah, S., dan Mulyono, P., 2012, Degradasi substrat volatile solid pada produksi biogas dari limbah pembuatan tahu dan kotoran sapi, Jurnal Rekayasa Proses, 6 (1), 14-19

Yadvika, S., Sreekrishnan, T. R., Kohli, S., and Rana, V., 2004, Enhancement of biogas production from solid substrates using different techniques - A review, Bioresour. Technol., 95 (1), 1-10. 